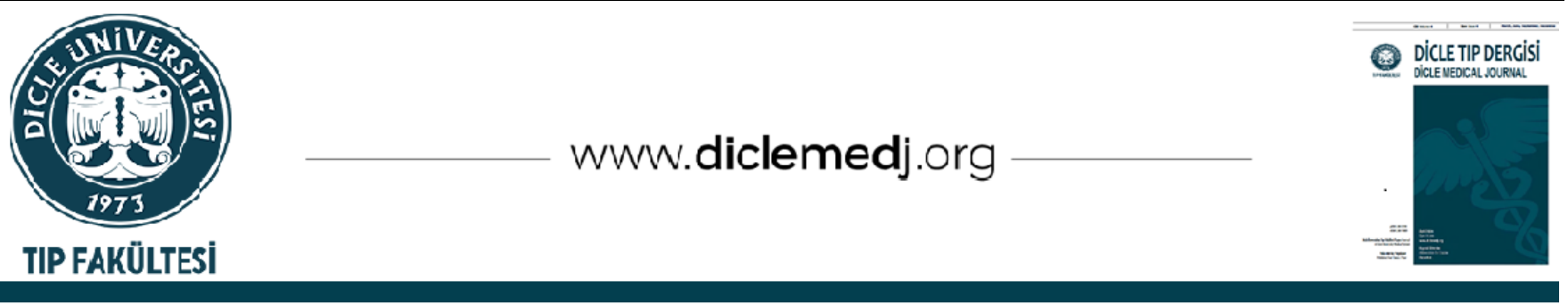

Original Article / Özgün Araştırma

\title{
Comparison of Effects of Ketamine, Esmolol and Lidocaine on Propofol Injection Pain
}

\author{
Döndü Genç Moralar ${ }^{\left(D_{1}\right.}$, Aygen Ülkü Türkmen ${ }^{i}{ }_{1}$, Aysel Hatice Altan ${ }^{i}{ }_{2}$ \\ 1 Department of Anesthesiology and Reanimation, Health Sciences University, Gaziosmanpaşa Training and Research Hospital, Istanbul, \\ Turkey \\ 2 Department of Anesthesiology, Aydın University High School of Medicine, Istanbul, Turkey
}

Received: 21.08.2020; Revised: 23.09.2021; Accepted: 24.09.2021

\begin{abstract}
Objective: Propofol is the most frequently used agent for intravenous anesthesia administration. However, during propofol injection, pain may develop in the hand and forearm region and cause unwanted situations. Different applications have been used to prevent propofol injection pain. Although lidocaine is often used for proprofol injection pain, anesthetic agent ketamine, which has an analgesic feature, is also preferred. In recent years, the analgesic feature of esmolol, a short-acting beta blocker, has been emphasized.

Our aim was to evaluate the effects of three different agents, ketamine, esmolol or lidocaine, on the severity of pain developing by propofol injection. Also, hemodynamic effects were investigated.
\end{abstract}

Methods: Sixty cases in ASA groups I and II, aged from 18 to 80 years old undergoing elective operations included in the study. To reduce the pain due to propofol injection, patients were given either $0.5 \mathrm{mg} / \mathrm{kg}$ ketamine, $0.5 \mathrm{mg} / \mathrm{kg}$ esmolol $\mathrm{HCl}$ or 0.5 $\mathrm{mg} / \mathrm{kg}$ lidocaine.

For induction 1\% propofol injection was administered, presence and severity of pain in the arm was questioned and recorded. To evaluate the severity of pain developing due to propofol injection, a 4-point numerical scale was used (no pain: 1, mild pain: 2, moderate pain: 3 and severe pain: 4). Arm pull motion was also recorded.

Results: There were no significant differences between the groups according to the severity of pain and pulling arm rates. There was no significant difference between hemodynamic parameters in the groups preoperatively, first, 5th, 10th, 15th, 20th and 30th minute.

Conclusion: Ketamine, esmolol, and lidocaine can safely control the severity of pain developing by propofol injection. Esmolol, ketamine and lidocaine provided effective analgesia at the doses used in our study without affecting the hemodynamic findings of the patients.

Keywords: Propofol injection pain, analgesic effect, esmolol, ketamine, lidocaine

DOI: 10.5798/dicletip.1001895

Correspondence / Yazıșma Adresi: Döndü Genç Moralar, Department of Anesthesiology and Reanimation, Health Sciences University, Gaziosmanpaşa Training and Research Hospital, Istanbul, Turkey e-mail: dondugencm@gmail.com 


\section{Ketamin, Esmolol ve Lidokainin Propofol Enjeksiyon Ağrısı Üzerine Etkilerinin Karşılaştırılması}

Öz

Giriş: Propofol, intravenöz anestezi uygulamasında en sık kullanılan ajandır. Ancak propofol enjeksiyonu sırasında el ve ön kol bölgesinde ağrı meydana gelmekte ve istenmeyen durumlara sebep olmaktadır. Propofol enjeksiyon ağrısını önlemek için farklı uygulamalar kullanılmaktadır. Proprofol enjeksiyon ağrısı için lidokain sıklıkla kullanılmakla birlikte, analjezik özelliği de olan, anestezik ajan ketamin de tercih edilmektedir. Son yıllarda kısa etkili beta bloker olan esmololün analjezik özelliği üzerinde durulmaktadır.

Çalışmamızın amacı, ketamin, esmolol veya lidokainin propofol enjeksiyonuyla gelişen ağrının şiddeti üzerindeki etkilerini değerlendirmek ve hemodinamik etkilerini araştırmaktır.

Yöntemler: Yaşları 18-80 aralığında olan, ASA I, II grubunda elektif operasyon uygulanan, 60 olgu çalışmaya dahil edildi.

Propofol enjeksiyonu öncesinde ağrı şiddetini azaltmak için hastalara 0,5 mg/kg lidokain, 0,5 mg/kg ketamin, 0,5 mg/kg esmolol HCl verildi. İndüksiyonda \% 1 propofol ile enjeksiyon yapılan kolda ağrı varlığı ve şiddeti sorularak kaydedildi. Propofol enjeksiyonuna bağlı olarak gelişen ağrı şiddetinin değerlendirmesi 4’lü sayısal skala (ağrısız:1, hafif ağrı:2, orta şiddette ağrı:3, şiddetli ağrı:4) kullanılarak yapıldı, kol çekme hareketi kaydedildi.

Bulgular: Ağrı şiddeti ve kol çekme oranları açısından gruplar arasında anlamlı fark bulunmadı. Ameliyat öncesi, 1, 5, 10, 15, 20, 30. dakikalarda hemodinamik parametreler arasında anlamlı fark yoktu.

Sonuç: Ketamin, esmolol ve lidokain ile propofol enjeksiyonuna bağlı olarak gelişen ağrı şiddeti hemodinamik etkilere yol açmadan güvenle kontrol edilmiştir. Esmolol, ketamin ve lidokain çalışmamızda kullanılan dozlarda, hastaların hemodinamik bulgularını etkilemeden etkin analjezi sağlamıştır.

Anahtar kelimeler: Propofol enjeksiyon ağrısı, analjezik etki, esmolol, ketamin, lidokain.

\section{INTRODUCTION}

Propofol is the most frequently used agent for intravenous anesthesia administration. However, during propofol injection, pain develops in the hand and forearm region and may cause unwanted situations.

It is reported that the incidence of propofol injection pain ranges from $28 \%$ to $90 \%$ in adults and $28 \%$ to $85 \%$ in children in the absence of other pretreatments ${ }^{1}$.

During the induction, pain felt by the patient may increase anxiety and cause sympathetic stimulation.

Painful stimulation causing the arm-pull reflex in unconscious patients may cause dangerous situations like pulling the intravenous catheter out of the vein ${ }^{2}$.

Different applications have been used to prevent propofol injection pain in clinical anesthesia practice. Various factors, including propofol temperature, and the concomitant use of various drugs appear to influence this pain ${ }^{3-5}$. Additionally to prevent propofol pain various agents such as dexmedetomidine, remifentanil, nitroglycerine, fentanyl, and magnesium have been used and found to reduce propofol injection pain ${ }^{6-12}$.

In our study, the aim was to evaluate the effects of three different agents, ketamine, esmolol or lidocaine, on the severity of pain developing by propofol injection. Hemodynamic effects on systolic arterial pressure (SAP), diastolic arterial pressure (DAP) and heart rate (HR) were investigated.

\section{METHODS}

Sixty cases in ASA groups I and II, undergoing elective operations at Okmeydanı Training and Research Hospital in the Anesthesia Clinic aged from 18 to 80 years old were included in the study after receiving ethics committee 
permission (approval date: 05.11.2013, numbered: 143).

Patients who underwent elective surgery with ASA 1, 2 were included in the study. Patients with chronic pain syndrome, thrombophlebitis, physical disorders, neurological diseases, pregnancy, hypertension, hypotension, ischemic heart disease, allergy and those using analgesics were excluded from the study.

A 22 gauge cannula was inserted into a vein on the back of the hand and $0.9 \%$ isotonic infusion was initiated. No premedication was applied to the patients who participated in the study.

A tourniquet was applied on the upper arm and injections of pretreatments drugs such as ketamine, esmolol or lidocaine were started. The pretreatments drugs were injected over a period of 10 seconds. The tourniquet was kept during the injection $(10 \mathrm{sec})$ and thirty second after the injection. Thirty second after the injecting pre-treatment drugs, the tourniquet was removed and then propofol was injected through angiocatheter over a period of 20 second $(10 \mathrm{mg} / \mathrm{sec})$.

Before propofol injection, to reduce the severity of pain, $0.5 \mathrm{mg} / \mathrm{kg}$ ketamine, $0.5 \mathrm{mg} / \mathrm{kg}$, esmolol $\mathrm{HCl}$ or $0.5 \mathrm{mg} / \mathrm{kg}$ lidocaine were administered to the arm with a tourniquet. During induction with $1 \%$ propofol injection, the presence and severity of pain in the arm was questioned and recorded. To evaluate the severity of pain due to propofol injection, a 4-point numerical scale was used (no pain:1, mild pain: 2, moderate pain: 3 and severe pain: 4 ). Arm pull motion was recorded.

For anesthesia induction, $2.5 \mathrm{mg} / \mathrm{kg}$ propofol and $0.6 \mathrm{mg} / \mathrm{kg}$ rocuronium were used. The patients were observed by dividing into three groups as those using ketamine (Group K), lidocaine (Group L), or esmolol (Group E) for propofol pain. There were 20 patients in each group. Fentanyl was administered after intubation and repeated every 30 minutes. While anesthesia maintenance was provided by $2 \%$ sevoflurane, $50 \% 02$ and $50 \%$ air.

After induction and at the first, 5th, 10th, 15th, 20th and 30th minute, SAP, DAP, and HR values were recorded. The hemodynamic response to intubation and side effects (nausea, vomiting, nystagmus, laryngospasm, excessive secretions, agitation, vision disorders, headache, allergic reactions) were also noted.

\section{Statistical Analysis}

In the pre-study evaluation, Standard Impact Size was determined as 0.92 with 5\% Error margin, and $80 \%$ Power. For each group, it was found to be sufficient to taken=19 as a model.

Data are presented using descriptive statistics as mean, standard deviation, median, minimum, maximum, frequency, and percentage. The distribution of variables was assessed with the Kolmogorov-Smirnov test. Quantitative data analysis used the ANOVA Kruskal-Wallis test. Analysis of qualitative data used the chi-square test, while the Fisher test was used if chi-square test conditions were not valid. Analyses were completed with the SPSS 22.0 program. The present study protocol was reviewed and approved by the ethics committee of Okmeydanı Teaching and Research Hospital (approval date: 05.11.2013, numbered: 143).

\section{RESULTS}

There was no significant difference $(p>0.05)$ between patients in Group K, Group E and Group L in terms of demographic data like age and body weight.

There was no significant difference ( $p>0.05)$ between Group K, Group E and Group L patients in terms of pain severity and arm-pull rates (Table 1). 
Table I: Propofol injection pain

\begin{tabular}{|c|c|c|c|c|c|c|c|c|}
\hline & \multicolumn{2}{|c|}{ Esmolol } & \multicolumn{2}{|c|}{ Ketamine } & \multicolumn{2}{|c|}{ Lidocaine } & \multirow[t]{2}{*}{$p$} \\
\hline & & $\mathrm{n}$ & $\%$ & $\mathrm{n}$ & $\%$ & $\mathrm{n}$ & $\%$ & \\
\hline \multirow{3}{*}{$\begin{array}{l}\text { Pain } \\
\text { scale }\end{array}$} & & & & 10 & & 18 & & $p>$ \\
\hline & Moderate & 0 & $0.0 \%$ & 1 & $5.0 \%$ & 1 & $5.0 \%$ & \\
\hline & Severe & 0 & $0.0 \%$ & 0 & $0.0 \%$ & 1 & $5.0 \%$ & \\
\hline \multicolumn{2}{|c|}{ Arm-pull } & 1 & $5.0 \%$ & 0 & $0.0 \%$ & 1 & $5.0 \%$ & $\begin{array}{l}p> \\
p .05\end{array}$ \\
\hline
\end{tabular}

There was no significant difference ( $p>0.05)$ between SAP, DAP, and HR mean arterial pressure and HR values in Group K, Group E and Group L preoperatively, first, 5th, 10th, 15th, 20th and 30th minute (Table 2-5) (Figure 1-4).

Table II: Systolic blood pressure

\begin{tabular}{|c|c|c|c|c|c|c|c|c|c|c|c|}
\hline \multirow{2}{*}{$\begin{array}{l}\text { Systolic } \\
\text { pressure }\end{array}$} & \multicolumn{4}{|c|}{ Esmolol } & \multicolumn{3}{|c|}{ Ketamine } & \multicolumn{3}{|c|}{ Lidocaine } & \multirow{2}{*}{$\mathrm{p}$} \\
\hline & & Mea & $\pm \mathrm{SD}$ & Median & Mea & $\pm \mathrm{SD}$ & Median & Mea & $\pm \mathrm{SD}$ & Median & \\
\hline At the start & & 133.2 & \pm 18.0 & 127.0 & 122.6 & \pm 20.5 & 128.0 & 136.7 & \pm 14.9 & 132.0 & 0.185 \\
\hline 1st minute & & 123.3 & \pm 25.2 & 127.0 & 128.2 & \pm 25.6 & 123.5 & 114.9 & \pm 8.5 & 112.0 & 0.370 \\
\hline 5th minute & & 123.5 & \pm 27.6 & 116.0 & 128.0 & \pm 19.8 & 130.5 & 117.9 & \pm 18.2 & 111.0 & 0.625 \\
\hline 10th minute & & 133.6 & \pm 24.7 & 126.0 & 117.6 & \pm 16.7 & 117.0 & 119.8 & \pm 19.8 & 120.0 & 0.132 \\
\hline 15th minute & & 125.3 & \pm 14.5 & 123.5 & 122.1 & \pm 17.3 & 113.0 & 123.0 & \pm 16.8 & 123.0 & 0.886 \\
\hline 20th minute & & 125.5 & \pm 14.0 & 132.0 & 118.6 & \pm 14.6 & 121.0 & 122.1 & \pm 27.7 & 107.0 & 0.701 \\
\hline 30th minute & & 127.6 & \pm 15.7 & 130.5 & 115.7 & \pm 15.1 & 112.5 & 135.9 & \pm 13.3 & 142.0 & 0.072 \\
\hline
\end{tabular}

ANOVA

Table III: Diastolic Bloood Pressure

\begin{tabular}{|c|c|c|c|c|c|c|c|c|c|c|c|}
\hline \multirow{2}{*}{$\begin{array}{l}\text { Diastolic } \\
\text { pressure }\end{array}$} & & \multicolumn{3}{|c|}{ Esmolol } & \multicolumn{3}{|c|}{ Ketamine } & \multicolumn{3}{|c|}{ Lidocaine } & \multirow[t]{2}{*}{$\mathrm{p}$} \\
\hline & & Mea & $n \pm S D$ & Median & Mea & $\pm \mathrm{SD}$ & Median & Mea & $\pm \mathrm{SD}$ & Median & \\
\hline At thestart & & 77.9 & \pm 11.6 & 79.0 & 80.0 & \pm 18.4 & 72.5 & 80.3 & \pm 9.6 & 81.0 & 0.880 \\
\hline 1st minute & & 77.5 & \pm 14.5 & 82.0 & 81.5 & \pm 19.9 & 76.5 & 73.6 & \pm 11.2 & 72.0 & 0.508 \\
\hline 5th minute & & 74.8 & \pm 21.1 & 72.0 & 87.4 & \pm 13.2 & 87.5 & 72.0 & \pm 10.1 & 70.5 & 0.094 \\
\hline 10th minute & & 80.9 & \pm 20.7 & 78.0 & 76.4 & \pm 11.7 & 77.0 & 73.0 & \pm 11.5 & 72.0 & 0.468 \\
\hline 15th minute & & 76.0 & \pm 13.7 & 80.5 & 78.9 & \pm 13.8 & 77.0 & 78.0 & \pm 12.4 & 73.0 & 0.869 \\
\hline 20th minute & & 80.7 & \pm 15.5 & 80.0 & 78.9 & \pm 16.2 & 77.0 & 73.3 & \pm 11.4 & 69.0 & 0.553 \\
\hline 30th minute & & 81.6 & \pm 12.5 & 84.5 & 72.0 & \pm 8.2 & 72.0 & 87.3 & \pm 8.9 & 81.0 & 0.056 \\
\hline
\end{tabular}


Table IV: Mean arterial pressure

\begin{tabular}{|c|c|c|c|c|c|c|c|c|c|c|}
\hline \multirow{3}{*}{$\begin{array}{l}\text { Mean } \\
\text { pressure }\end{array}$} & \multicolumn{3}{|c|}{ Esmolol } & \multicolumn{3}{|c|}{ Ketamine } & \multicolumn{3}{|c|}{ Lidocaine } & \multirow{2}{*}{$\mathrm{p}$} \\
\hline & \multicolumn{2}{|c|}{ Mean \pm SD } & \multirow[t]{2}{*}{ Median } & \multicolumn{2}{|c|}{ Mean \pm SD } & \multirow[t]{2}{*}{ Median } & \multicolumn{2}{|c|}{ Mean \pm SD } & \multirow[t]{2}{*}{ Median } & \\
\hline & & & & & & & & & & \\
\hline At thestart & 100.2 & \pm 11.6 & 101.0 & 98.1 & \pm 19.0 & 95.0 & 100.2 & \pm 11.4 & 99.0 & 0.927 \\
\hline 1st minute & 95.1 & \pm 16.2 & 99.0 & 100.4 & \pm 21.6 & 91.5 & 88.2 & \pm 10.3 & 84.0 & 0.247 \\
\hline 5th minute & 94.5 & \pm 23.2 & 92.0 & 105.9 & \pm 15.3 & 99.5 & 95.3 & \pm 13.1 & 99.0 & 0.286 \\
\hline 10th minute & 103.9 & \pm 21.5 & 99.0 & 92.3 & \pm 11.4 & 95.5 & 88.5 & \pm 12.7 & 85.5 & 0.070 \\
\hline 15th minute & 95.8 & \pm 16.4 & 96.5 & 97.4 & \pm 15.5 & 90.0 & 94.6 & \pm 16.2 & 100.0 & 0.929 \\
\hline 20th minute & 96.7 & \pm 15.9 & 103.0 & 95.4 & \pm 17.1 & 91.0 & 96.7 & \pm 14.9 & 95.0 & 0.984 \\
\hline 30th minute & 97.1 & \pm 14.3 & 99.5 & 90.5 & \pm 10.9 & 87.0 & 112.0 & \pm 3.0 & 112.0 & 0051 \\
\hline
\end{tabular}

Table V: Heart Rate

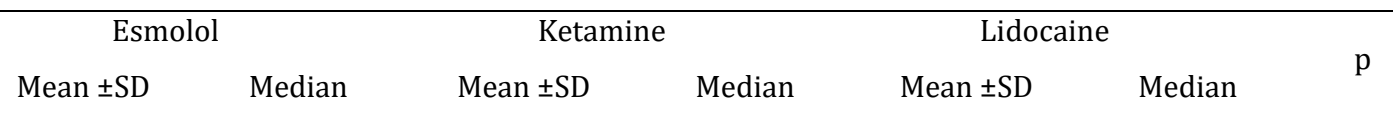

\begin{tabular}{lcccccccccc} 
Heart rate & & & & & & & & & \\
At the start & 92.8 & \pm 11.0 & 87.0 & 84.3 & \pm 14.7 & 86.0 & 89.0 & \pm 13.0 & 92.0 & 0.283 \\
1st minute & 89.0 & \pm 9.9 & 87.0 & 83.1 & \pm 11.3 & 86.0 & 93.1 & \pm 16.7 & 98.0 & 0.210 \\
5th minute & 82.1 & \pm 7.5 & 82.0 & 79.9 & \pm 12.1 & 76.0 & 85.3 & \pm 14.8 & 88.5 & 0.566 \\
10th minute & 86.5 & \pm 5.7 & 86.0 & 83.3 & \pm 11.5 & 86.5 & 78.4 & \pm 11.0 & 74.5 & 0.112 \\
15th minute & 82.1 & \pm 9.6 & 79.0 & 79.3 & \pm 7.0 & 77.0 & 84.0 & \pm 18.9 & 74.0 & 0.722 \\
20th minute & 81.5 & \pm 15.0 & 80.0 & 83.0 & \pm 11.3 & 84.0 & 88.9 & \pm 9.0 & 94.0 & 0.481 \\
30th minute & 83.2 & \pm 11.0 & 82.0 & 75.4 & \pm 13.8 & 76.0 & 80.4 & \pm 10.4 & 75.0 & 0.441 \\
\hline
\end{tabular}

\section{ANOVA}

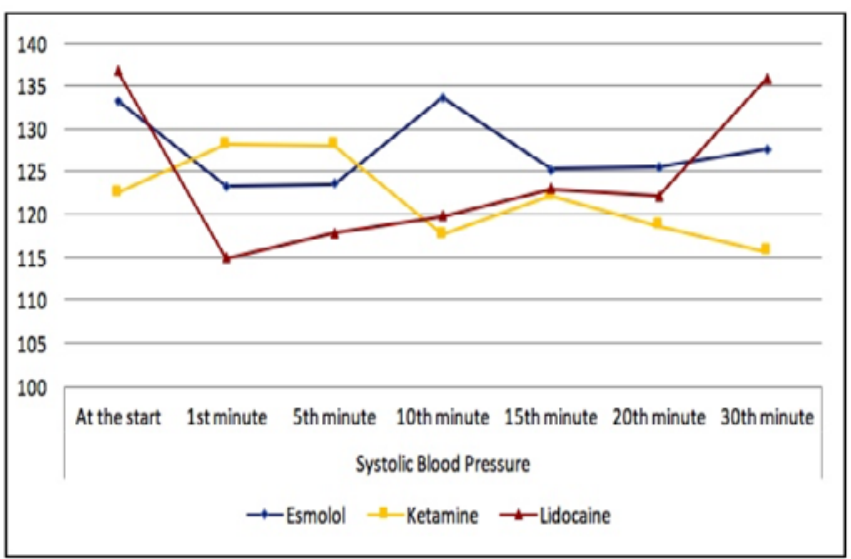

Figure 1. Systolic blood pressure

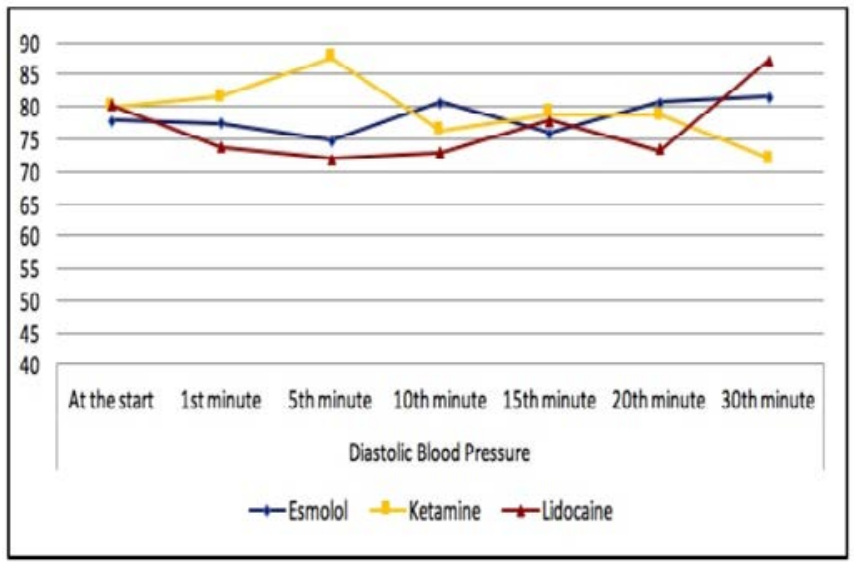

Figure 2. Diastolic Bloood Pressure 


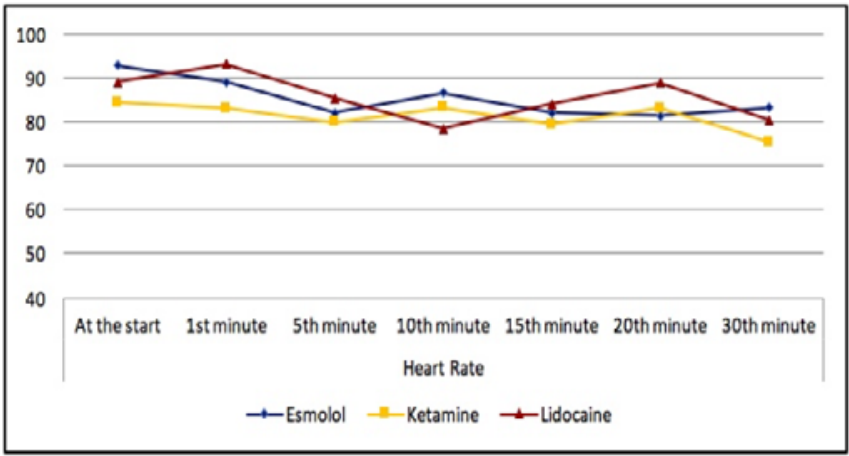

Figüre 3. Mean arterial pressure

There were no significant differences ( $p>0.05)$ between Group K, Group E and Group L patients in terms of nausea, vomiting, laryngospasm,

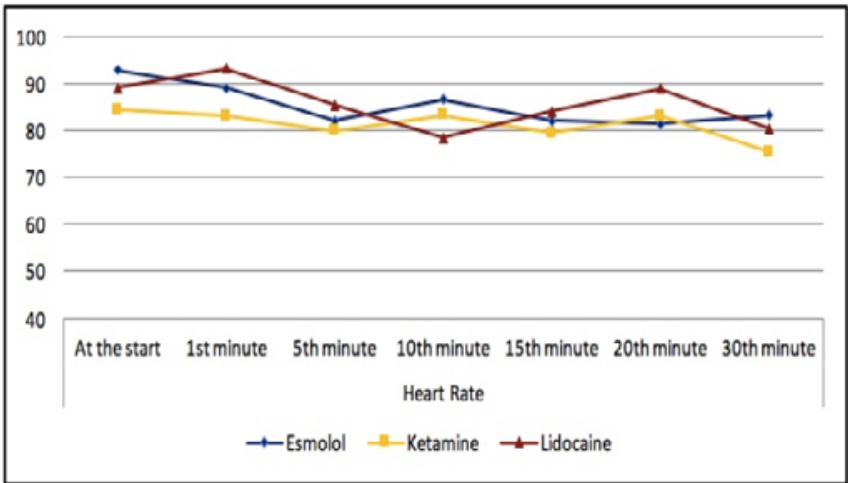

Figure 4. Heart Rate

nystagmus, excessive secretion, bronchospasm, headache, vision disorders, allergic reactions and erythema (Table 6).

Table VI: Side effects

\begin{tabular}{|c|c|c|c|c|c|c|c|}
\hline \multirow[b]{2}{*}{ Nausea } & \multicolumn{2}{|c|}{$\begin{array}{l}\text { Esmolol } \\
\mathrm{n}-\%\end{array}$} & \multicolumn{2}{|c|}{$\begin{array}{l}\text { Ketamine } \\
\mathrm{n}-\%\end{array}$} & \multicolumn{2}{|c|}{$\begin{array}{l}\text { Lidocaine } \\
\text { n-\% }\end{array}$} & \multirow{2}{*}{$\begin{array}{c}\mathrm{p} \\
\mathrm{p}>0.05\end{array}$} \\
\hline & 0 & $0.0 \%$ & 0 & $0.0 \%$ & 0 & $0.0 \%$ & \\
\hline Vomiting & 0 & $0.0 \%$ & 0 & $0.0 \%$ & 0 & $0.0 \%$ & $p>0.05$ \\
\hline Nystagmus & 0 & $0.0 \%$ & 1 & $5.0 \%$ & 0 & $0.0 \%$ & $p>0.05$ \\
\hline Excessive secretion & 0 & $0.0 \%$ & 0 & $0.0 \%$ & 0 & $0.0 \%$ & $p>0.05$ \\
\hline Laryngospasm & 0 & $0.0 \%$ & 0 & $0.0 \%$ & 0 & $0.0 \%$ & $p>0.05$ \\
\hline Bronchospasm & 0 & $0.0 \%$ & 1 & $5.0 \%$ & 0 & $0.0 \%$ & $p>0.05$ \\
\hline Headache & 0 & $0.0 \%$ & 0 & $0.0 \%$ & 0 & $0.0 \%$ & $p>0.05$ \\
\hline Visiondisorders & 0 & $0.0 \%$ & 0 & $0.0 \%$ & 0 & $0.0 \%$ & $p>0.05$ \\
\hline Allergic reaction & 1 & $5.0 \%$ & 0 & $0.0 \%$ & 0 & $0.0 \%$ & $p>0.05$ \\
\hline Erythema at injection site & 2 & $10.0 \%$ & 0 & $0.0 \%$ & 0 & $0.0 \%$ & $\mathrm{p}>0.05$ \\
\hline
\end{tabular}

ANOVA / Kruskal-wallis / Ki-kare test (Fischer test)

\section{DISCUSSION}

Propofol, used as an intravenous anesthetic agent, is known to cause pain sensation during injection. However, the molecular mechanisms underlying this effect are not fully understood ${ }^{13}$.

A study by Nishimato et al. ${ }^{13}$ concluded that propofol may cause pain through multiple mechanisms involving TRPV1 (transient receptor potential vanilloid 1) and TRPA1 (transient receptor potential ankyrin 1) but also through activation of voltage-gated channels downstream of GABA A receptors.

Propofol activates the plasma kinin-kallikrein system freeing bradykinin and which causes local vein changes like venous dilatation and hyperpermeability. This situation allows propofol to contact more with free nerve endings causing pain. Nakane et al. ${ }^{14}$ found that the lipid solvent for propofol activates the plasma kallikrein-kinin system and produces bradykinin which modifies the injected local vein. This modification of the peripheral vein 
may increase contact between the aqueous phase propofol and the free nerve endings of the vessel, resulting in aggravation of propofolinduced pain.

Zahedi et al. ${ }^{15}$ compared different ketamine doses with lidocaine and found that $0,1 \mathrm{mg} / \mathrm{kg}$ ketamine administration before propofol injection was an effective and safe method in eliminating propofol pain.

Wang et al. ${ }^{16}$ observed that $0.3 \mathrm{mg} / \mathrm{kg}$ dose of ketamine was effective at resolving propofol pain in a study planned to determine an effective dose of ketamine to eliminate pain during propofol injection.

Zhao et al. ${ }^{17}$ in a pediatric study showed that 0.3 $\mathrm{mg} / \mathrm{kg}$ ketamine administration reduced the severity of propofol injection pain without causing serious side effects.

In another study, with $0.5 \mathrm{mg} / \mathrm{kg}$ ketamine, propofol injection pain was reduced while it was totally eliminated with $1.0 \mathrm{mg} / \mathrm{kg}$ ketamine. Ketamine completely eliminated pain without affecting hemodynamics ${ }^{18}$.

In our study, we found that $0,5 \mathrm{mg} / \mathrm{kg}$ ketamine provides effective analgesia without affecting hemodynamics.

Beside cardiac inhibitor effects, short-acting beta1-adrenergic receptor antagonists like esmolol are reported to exert anti-nociceptive and anesthetic sparing effects in animal and human subjects ${ }^{19}$.However, the direct mechanism underlying anti nociceptive effects of short-acting beta1-adrenergic receptor antagonists has not been fully established.

The pain and arm pull reaction was shown to decrease with pretreatment with esmolol19-21. Masaki19 considered that in the future, shortacting beta-adrenergic receptor antagonists would be used for anti-nociception.

It has been found that pretreatment with intravenous esmolol reduces propofol injection pain $^{22}$.
In our study, we found that esmolol reduced propofol injection pain. When compared with ketamine and lidocaine, esmolol had similar effects on injection pain.

Lidocaine is known to effectively reduce propofol pain ${ }^{6,7,23-25}$. Ayatollahi et al. ${ }^{26}$ identified a similar efficacy of with ketamine and lidocaine in a study.

In our study, we identified effective treatment in all three groups.

When we examine them in term of side effects and hemodynamic effects, in our study doses of $0.5 \mathrm{mg} / \mathrm{kg}$ ketamine, esmolol or lidocaine used did not produce a significant difference in hemodynamic response and we reliably provided effective pain treatment.

\section{Limitation}

Our study was conducted with 60 patients. Multicenter studies with more patients are needed. In our study, doses used in the literature were used to prevent propofol injection pain, and in our study, effective analgesia was provided without any side effects. However, studies on more patients are needed to investigate whether the same effect can be achieved with lower doses.

As a conclusion, there was no difference in pain scales between the three groups in preventing profopol injection pain, and its analgesic properties were found to be similar. In addition, when the hemodynamic effects of all three agents were compared, it was observed that there was no difference between them. We consider that ketamine, esmolol, and lidocaine safely controlled the severity of pain developed by to propofol injection without causing hemodynamic effects. There is a need for studies on this topic.

Acknowledgments:The authors thank all colleagues who help for patients' data collection. 
Ethics Committee Approval: The present study protocol was reviewed and approved by the ethics committee of Okmeydanı Teaching and Research Hospital (approval date: 05.11.2013, numbered: 143).

Conflict of Interest: The authors declared no conflicts of interest.

Financial Disclosure: The authors declared that this study has received no financial support.

\section{REFERENCES}

1. Stark R, Binks S, Dutka V, et al. A review of thesafetyandtoler $\neg$ ance of propofol (Diprivan) PostgradMed J 1984; 61: 152-6.

2. Lui JT, Huang SJ, Yang CY, et al. Rocuroniuminduced generalized spontaneous movements cause pulmonary aspiration. Chang Gung Med J 2002; 25: 617-20.

3. Jalota L, Kalira V, George E, et al. Prevention of pain on injection of propofol: systematic review and meta-analysis. BMJ 2011; 15:342.

4. Picard $P$ andTramer MR. Prevention of pain on injection with propofol: a quantitative system $\neg$ atic review. Anesth Analg 2000; 90: 963-9.

5. Demir A, Aydınlı B, Tezcan, et al. Influence of Temperature and $\mathrm{pH}$ Changes on Propofol Injection Pain. Turk J Anaesth Reanim 2013; 41: 34-7.

6. Sun J, Zhou R, Lin W, et al. Magnesium sulfate plus lidocaine reduces propofol injection pain: a doubleblind, randomized study. Clin Ther 2016; 38: 31-8.

7. Sapate M, Andurkar U, Markandeya M, et al. To study the effect of injection dexmedetomidine for prevention of pain dueto propofol injection and to compare it with injection lignocaine. Braz J Anesthesiol 2015; 65: 466-9.

8. Uliana GN, Tambara EM, Baretta GA. Use of remifentanil to reduce propofol injection pain and the required propofol dose in upper digestive tract endoscopy diagnostic tests. Braz J Anesthesiol 2015; 65: 437-4.

9. Kizilcik N, Menda F, Bilgen S, et al. Effects of a fentanyl-propofol mixture on propofol injection pain: a randomized clinical trial. Korean J Anesthesiol 2015; 68: 556-60.
10. Karbasy S.H, Bahador R. Theeffects of nitroglycerine on pain control during the propofol injection; a controlled, double-blinded, randomized clinical trial. Anesth Pain Med 2015;5: e26141.

11. M, Zhao X, Zhang L, et al. Effects and safety of magnesium sulfate on propofol-induced injection pain, a meta-analysis of randomized controlled trials.Int J Clin Exp Med 2015;8: 6813-21.

12. Sarkılar G, Kara İ, Duman A, et al. Effect of dexmedetomidine on paincaused by injection of propofol. Nobel Med 2012; 8: 83-8.

13. Nishimoto R, Kashio M, Tominaga M. Propofolinduced pain sensation involves multiple mechanisms in sensoryneurons. Propofol-induced pain sensationin volves multiple mechanisms in sensoryneurons. Pflugers Arch 2015;467: 2011-20.

14. Nakane M, Iwoma H. A potential mechanism of propofol-induced pain on injection based on studies using nafamostat mesilate. Br J Anaesth 1999; 83: 397-404.

15. Zahedi $H$, Nikooseresht $M$, Seifrabie $M$. Prevention of propofol injectionpainwith smalldoseketamine. Middle East J Anaesthesiol 2009; 20: 401-4.

16. Wang $M$, Wang $Q$, Yu YY, Wang WS. An effectivedose of ketamine for eliminating pain during injection of propofol: a dose response study. Ann Fr Anesth Reanim 2013;32: e103-6.

17. Zhao GY, Guo Y, Bao SM, Meng LX, Zhang LH. Prevention of propofol-induced pain in children: pretreatment with small doses of ketamine. J Clin Anesth 2012; 24: 284-8.

18. Iwata $M$, Inoue $S$, Kawaguchi $M$, et al. Ketamine eliminates propofol pain but does not affect hemodynamics during induction with double-lumen tubes. J Anesth 2010;24: 31-7.

19. Masaki E. Antinociceptive effects of landiolol and esmolol. Masui. 2006;55: 849-55.

20. Ergil J, Kavak Akelma F, Özkan D, et al. Effects of pretreatment with esmolol and lidocaine on injection pain and rocuronium-induced with drawal response. Turk J MedSci 2015;45: 959-63.

21. Yavascaoglu B, Kaya FN, Ozcan B. Esmolol pretreatment reduces the frequency and severity of 
pain on injection of rocuronium. J Clin Anesth 2007;19: 413-7.

22. Akgün SE, Titiz L, Akpek E, Arslan G. Pretreatment with a very low dose of intravenous esmolol reduces propofol injection pain. Ağrı 2013; 25: $13-8$.

23. Kelsaka E, Barış S, Tepe Ş, et al . Propofol Enjeksiyon Ağrısının Önlenmesinde Ondansetron Ve Lidokainin Karşılaştırılması. J Exp Clin Med 2009; 19: 263-7.

24. Tian S, Zhang D, Zhou W, et al. Median Effective Dose of Lidocaine for the Prevention of ain Caused by the Injection of Propofol Formulated with Medium- and Long-Chain Triglycerides Based on Lean Body Weight. Pain Med 2021 4;22: 1246-52.

25. Ghimire B, Bahadur Chand M. Lidocaine for Reduction of Pain Induced by Propofol in a Tertiary Care Hospital: A Descriptive Cross-sectional Study. JNMA J Nepal Med Assoc 2021 30;59: 365-8.

26. Ayatollahi V, Behdad S, Kargar S, Yavari T. Comparison of effects of ephedrine, lidocaine and ketamine with placebo on injection pain, hypotension and bradycardia due to propofol injection: a randomized placebo controlled clinical trial. Acta Medica Iranica 2012; 50: 609-14. 